\title{
LIM Homeodomain (LIM-HD) Genes and Their Co-Regulators in Developing Reproductive System and Disorders of Sex Development
}

\author{
Neha Singh Domdatt Singh Deepak Modi \\ Molecular and Cellular Biology Laboratory, ICMR-National Institute for Research in Reproductive Health, Indian \\ Council of Medical Research (ICMR-NIRRH), Mumbai, India
}

\section{Keywords}

Gonad $\cdot$ Homeobox $\cdot$ Infertility · Ovary $\cdot$ Puberty $\cdot$ Sex

determination · Testis · Uterus mouse gonads. Unraveling the roles of LIM-HD genes during development will aid in our understanding of the causes of DSD.

\begin{abstract}
LIM homeodomain (LIM-HD) family genes are transcription factors that play crucial roles in a variety of functions during embryonic development. The activities of the LIM-HD proteins are regulated by the co-regulators LIM only (LMO) and LIM domain-binding (LDB). In the mouse genome, there are 13 LIM-HD genes (Lhx1-Lhx9, Is/1-2, Lmx1a-1b), 4 Lmo genes ( $L m o 1-4)$, and 2 Ldb genes ( $L d b 1-2)$. Amongst these, $L h x 1$ is required for the development of the müllerian duct epithelium and the timing of the primordial germ cell migration. $L h x 8$ is necessary for oocyte differentiation and $L h x 9$ for somatic cell proliferation in the genital ridges and control of testosterone production in the Leydig cells. Lmo4 is involved in Sertoli cell differentiation. Mutations in LHX1 are associated with müllerian agenesis or Mayer-Rokitansky-KusterHauser (MRKH) syndrome. LHX9 gene variants are reported in cases with disorders of sex development (DSD). Mutations in $L H X 3$ and $L H X 4$ are reported in patients with combined pituitary hormone deficiency having absent or delayed puberty. A transcript map of the $L h x, L m o$, and $L d b$ genes reveal that multiple LIM-HD genes and their co-regulators are expressed in a sexually dimorphic pattern in the developing
\end{abstract}

\section{Introduction}

Disorders of sex development (DSD) are defined as congenital conditions where the chromosomal, gonadal, or anatomic sex is atypical [Hughes et al., 2006; Lee et al., 2006, 2016]. The estimated incidence of DSD is approximately 1 in 4,500-5,500 newborns, but including cryptorchidism and hypospadias within, the incidence can be range from 1:200 to 1:300 [García-Acero et al., 2020]. Considering that sexual and gender identity is central to the psychosocial wellbeing of an individual, an understanding of the causes of DSD is crucial toward the development of diagnostic and management modalities of these patients. Chromosomal abnormalities, mutations in genes required for gonad development, differentiation, and hormone biosynthesis or hormone receptors lead to DSD [Witchel, 2018; Gomes et al., 2020]. However, these genetic alterations account for only $20 \%$ of cases [Eggers et al., 2016], and in most patients, the cause of DSD cannot be established. Exome sequencing of patients with DSD has identified several variants in a large number of karger@karger.com www.karger.com/sxd
(C) 2021 S. Karger AG, Basel

Karger!
Correspondence to:

Deepak Modi, deepaknmodi@yahoo.com 
genes in these patients, suggesting that DSD are multigenic in nature [Bashamboo et al., 2017; Wang et al., 2018; Witchel, 2018; Gomes et al., 2020]. These studies have further defined the cause of DSD in $40-60 \%$ of patients, yet several cases remain unexplained [Arboleda et al., 2014; Eggers et al., 2016; Wang et al., 2018]. Further, in most cases, functional studies are lacking, and in many instances, the variants are of unknown significance. Thus, there is a need to expand our basic understanding of the process of gonadal development to aid further in ascribing the enigma of DSD.

Gonad development initiates with the formation of the urogenital ridge from proliferating coelomic epithelium on the ventral surface of mesonephros which makes up the somatic niche [Rotgers et al., 2018; Yang et al., 2019]. The primordial germ cells (PGCs) first emerge from the extra-embryonic mesoderm and eventually migrate into the elongated and narrow genital ridges to form the bipotential gonad [Richardson and Lehmann, 2010; Harikae et al., 2013; Tang et al., 2016; Stévant and Nef, 2019]. The bipotential gonads, by an intricate network of intragonadal factors, undergo sex determination to acquire either 1 of the 2 fates, testis or ovary [Singh and Modi, 2020]. In mammals, differentiation of the bipotential gonad depends on the chromosomal cues where the Sry gene on the $\mathrm{Y}$ chromosome triggers the differentiation of the testicular fate [Gubbay et al., 1990; Koopman et al., 1990]. Activation of SRY in the somatic cells drives the Sry-Sox9-Fgf9-Amh cascade, resulting in Sertoli cell differentiation. In XX embryos, the absence of Sry leads to activation of the female cascade mediated through Wnt4/ Rspo1/ $\beta$-catenin/Foxl 2 and hence ovarian fate [Rotgers et al., 2018; Stévant and Nef, 2019]. These 2 mutually opposing sets of genetic players decide the fate of all the cell types in the bipotential gonads resulting in a functional testis or an ovary.

Our knowledge of the genetic networks that operate during sex determination and differentiation of the reproductive system is far from clear. With the advent of high throughput transcriptome analysis coupled with genomic analysis of individuals with DSDs, we have now been able to gather pieces of the sex determination puzzle. To date, several members of signaling pathways and transcription factors have been identified to play an indispensable role in sex determination. Amongst the signal transducers, the members of the fibroblast growth factor (FGF) family, transforming growth factor (TGF) superfamily including bone morphogenetic proteins (BMPs) and Hedgehogs, members of the wingless-type MMTV integration site (WNT) family, the Notch signaling path- way components, and the members of the mitogen-activated protein kinase (MAPK) family are extensively studied in the context of sex determination [Kim and Capel, 2006; Biason-Lauber, 2012; Fan et al., 2012; Franco and Yao, 2012; Warr et al., 2012; Chassot et al., 2014; Eggers et al., 2014; Dong et al., 2015; Wear et al., 2016; Windley and Wilhelm, 2016; Monsivais et al., 2017]. Amongst the transcription factors, the high-mobility group (HMG) members, mainly the $S R Y$ and SOX genes, the doublesex, and mab-3 related transcription factor (DMRT) family, GATA family members, and their co-factors, have been extensively studied in the context of gonad development [Clarkson and Harley, 2002; Windley and Wilhelm, 2016; Huang et al., 2017; Tremblay et al., 2018].

Homeobox genes are evolutionarily conserved genes encoding homeodomain-containing transcription factors that act in a variety of contexts during embryonic development and adult functions [Banerjee-Basu and Baxevanis, 2001; Srivastava et al., 2010; Ashary et al., 2020]. Curiously, despite their indispensable roles in many developmental processes, the involvement of homeobox genes in gonad development and sex determination is largely unexplored [Svingen and Koopman, 2007]. The homeobox genes in animals consist of 11 classes of gene families which include ANTP, PRD, LIM, POU, HNF, SINE, TALE, CUT, PROS, ZF, and CERS [Holland et al., 2007; Ferrier, 2016]. These genes have a key role in patterning during animal development and are also linked to the evolution of specialized functions of body plans. Amongst these, the genes of the LIM homeobox $(L h x)$ family have central roles in cell fate determination, tissue-specific differentiation, and body patterning in a variety of vertebrates and invertebrates. In the context of reproduction, the roles of specific $L h x$ genes mainly in the müllerian duct development have been studied and reviewed [Cunha et al., 2018; Gonzalez et al., 2021]. However, a comprehensive understanding of the $\operatorname{Lh} x$ gene family in sexual development is lacking. Herein, we review the current knowledge on the roles of LIM-homeodomain family members in reproductive development and cause of DSD.

\section{LIM-Homeodomaim Gene Family}

LIM-homeodomain (LIM-HD) genes belong to the extended homeobox gene family and have been a subject of intense interest in terms of their roles in understanding evolution and development [Srivastava et al., 2010; Koch et al., 2012; Bürglin and Affolter, 2016; Ferrier, 2016; McMahon 
et al., 2019]. LIM-homeobox genes encode regulatory proteins which are transcription factors containing 2 tandemly repeated LIM domains at the $\mathrm{N}$-terminus separated by 2 amino acids, a centrally located conserved DNA-binding homeodomain and a C-terminally located random domain [Bach, 2000; Zheng and Zhao, 2007; Matthews et al., 2009]. The acronym LIM comes from the initials of 3 homeodomain proteins, $\underline{\operatorname{Lin} 11}$ and $\underline{\mathrm{Mec}}-3$ in C. elegans and $\underline{\mathrm{I}} \mathrm{s}-1$ from rat in which the motifs were first discovered [Bach, 2000; Matthews et al., 2009]. The LIM domain is a cysteine-histidine-rich, zinc-coordinating domain and is highly conserved from ascidians to humans [Bach, 2000]. The LIM domains of the LIM-HD genes participate in protein-protein interactions to form multiprotein complexes (reviewed below) and regulate diverse cell function. Not surprisingly, LIM-HD proteins are well known for their function in a variety of developmental processes, such as body axis patterning, dorso-ventral patterning, tissue patterning, cell specification, and cell proliferation in a variety of tissues [Zhou et al., 2015; Chou and Tole, 2019; McMahon et al., 2019; Monahan et al., 2019].

\section{LIM Homeodomain Genes in Gonad Development}

The human genome contains 58 proteins with 135 LIM domains [Kadrmas and Beckerle, 2004; Matthews et al., 2009] out of which 12 are LIM-HD members. In mouse, 13 LIM-HD proteins are known [Bulchand et al., 2003]. These genes are categorized into 6 paralogous subclasses based on their sequence homology and function [Srivastava et al., 2010; Wang et al., 2014]. Amongst these, the role of 3 LIM-HD genes, $L h x 1, L h x 8$, and $L h x 9$, are known in various aspects of gonad and reproductive tract development. Lhxl is required for development of the müllerian ducts, $L h x 9$ is necessary for the development of the bipotential gonad, while $L h x 8$ is crucial in folliculogenesis. Reviewed below are the roles of these genes in the development of the reproductive system.

\section{LIM Homeobox Gene 1 (Lhx1)}

$\operatorname{Lhx} 1(\operatorname{Lim} 1)$ is the most extensively studied gene in a range of animals. $L h x 1$ is expressed in intermediate mesoderm, mesonephros, metanephros, fetal gonads, and precursor cells of müllerian ducts in a variety of species [Tsang et al., 2000]. In invertebrates, a Lim1-like gene has been identified in C. elegans (Lin-11), drosophila (dlim1), sea urchin (HpLiml) (Hemicentrotus pulcherrimus and Strongylocentrotus purpuratus), bivalves (Mytilus galloprovincialis), and is expressed in the developing nervous system, vulva, and gonads [Torrado and Mikhailov, 2000]. Amongst the vertebrates, $\operatorname{Lim} 1$ is expressed in the embryonic nervous system and urogenital system of fishes, chickens, mice, rats, and humans [Torrado and Mikhailov, 2000]. In Dabry's sturgeon, $L h x 1$ is expressed significantly higher in gonads of females than in males [Chen et al., 2018]. On the contrary, Lhxl is enriched in the testis of Chinese sturgeon [Yue et al., 2015].

The expression of $L h x 1$ in the developing mouse reproductive system begins in the gonadal region, intermediate mesoderm and nephrogenic cord, and then becomes limited to the epithelium of the developing müllerian duct around E11.5 [Barnes et al., 1994; Kobayashi et al., 2004]. The expression becomes sexually dimorphic at E15.5 with persistent strong expression in paramesonephric ducts of XX embryos and a weaker expression in mesonephric ducts of XY embryos (Fig. 1). At this time Lhx1 is strongly expressed in the regressing paramesonephric ducts of the XY embryos (not shown, please visit https://www.gudmap.org/for details). At 15 days post coitum, Lhx1 mRNA is also sexually dimorphic in the gonads with higher expression in the ovary as compared to the testis (Fig. 1).

Lhxl is crucial for the development of reproductive ducts in XX and XY embryos. Mice constitutively lacking Lhx1 die around E10.5 [Kobayashi et al., 2004]. Analysis of a small number of surviving female $L h x 1^{-/-}$neonates revealed an absence of the oviducts and uterus, establishing an essential role for $L h x 1$ in the formation of female reproductive tract [Kobayashi et al., 2004]. Besides the female neonates, loss of wolffian duct derivatives was also reported in one of the surviving $L h x 1^{-/-}$male neonates, indicating a role for $L h x 1$ in reproductive tract development in both sexes [Kobayashi and Behringer, 2003; Kobayashi et al., 2004]. Although a previous study had reported that $L h x 1^{-/-}$neonates did not develop gonads, kidney, and head [Shawlot and Behringer, 1995], eventually the presence of histologically normal gonads in the $\operatorname{Lh} \times 1^{-/-}$surviving neonates was shown [Kobayashi et al., 2004], suggesting that $\operatorname{Lh} x 1$ is dispensable for gonad formation.

To understand the mechanisms by which $L h x 1$ controls urogenital development, chimeric mice composed of $L h x 1^{-/-}$and wild-type cells [Kobayashi et al., 2004] or conditional knockouts using the Wnt7a-Cre [Huang et al., 2014] were analyzed. In the chimeric mouse pups, it was evident that the cells lacking $L h x 1$ did not contribute to the epithelium of the oviduct and the uterus, although these cells were present in the mesenchyme suggesting the possible involvement of LHX1 in epithelial cell bio- 
Fig. 1. Expression of $\operatorname{Lh} x 1, \operatorname{Lh} x 8$, and $\operatorname{Lh} x 9$ mRNA in mouse gonads and reproductive tract. mRNA expression of the genes on 15 days post coitum was accessed from GudMap project (https://www.gudmap.org/; accessed on May 17, 2021) and backed with published literature. Qualitative expression (low, moderate, and strong expression) for Lhxl (https://www.gudmap.org/ id/Q-4BVE@2W4-KWT6-DY9C), Lhx9 ( h t t p s : / / w w w. gud m a p.org / id/Q-4BVY@2W4-KWT6-DY9C), and Lhx8 (https://www.gudmap.org/id/Q4BVW@2W4-KWT6-DY9C) as mentioned in the GudMap [McMahon et al., 2008; Harding et al., 2011] was interpreted and drawn using Biorender (https://biorender.com/).

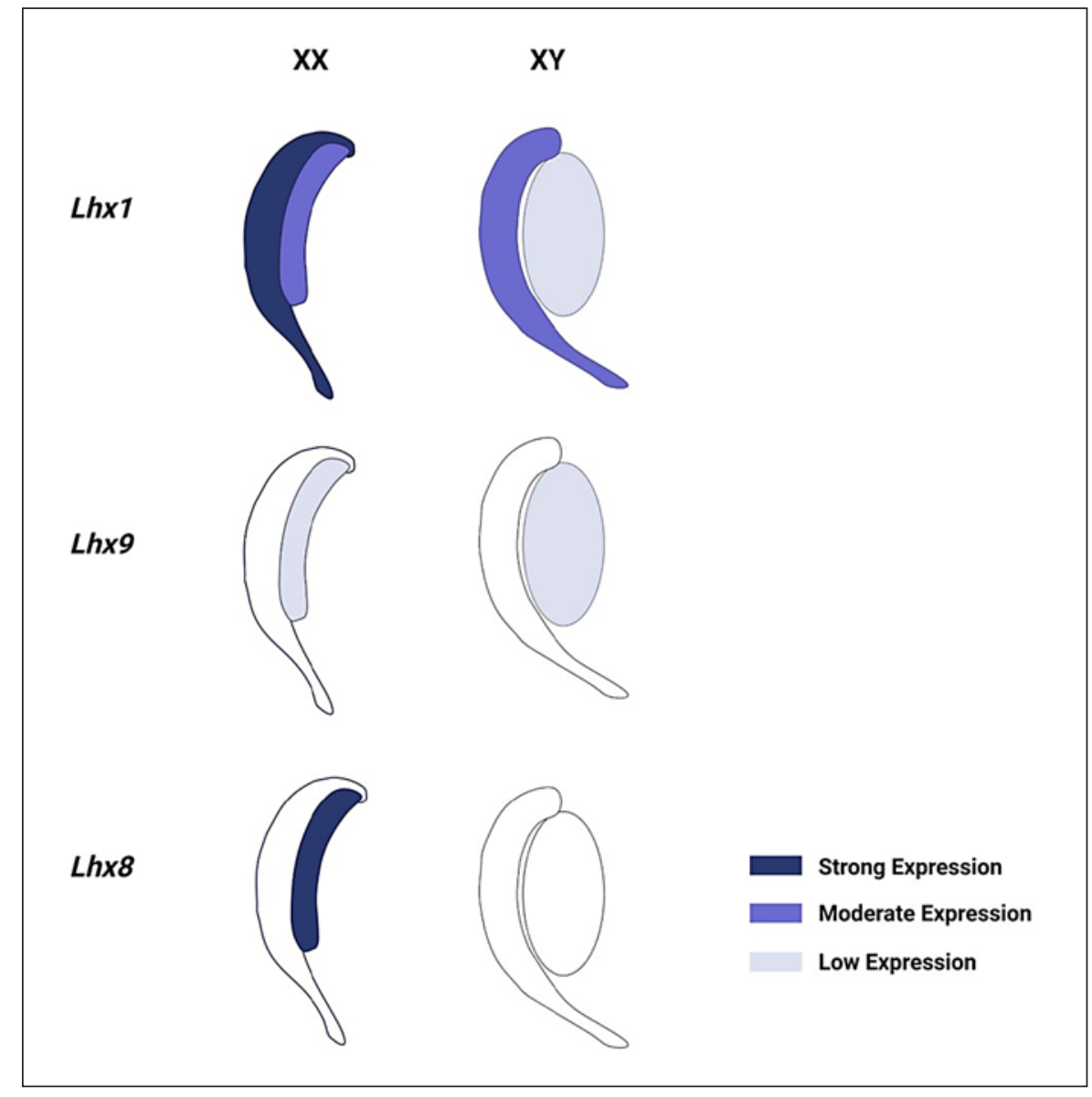

genesis of the müllerian duct. Indeed, conditional loss of Lhx1 in the epithelium (using Wnt7a-Cre) blocks müllerian duct elongation and the adult animals have uterine hypoplasia and absence of the luminal and glandular epithelium, suggesting that $L h x 1$ is required to maintain progenitor cells for müllerian ducts [Huang et al., 2014]. Together these results indicate that $L h x l$ is required cellautonomously for epithelium development of the uterus and oviduct in the mouse.

Lhxl seems to be also crucial for appropriate PGC migration and colonization. In some Lhx1-null embryos, a cluster of alkaline phosphatase-positive PGCs was found ectopically in the extraembryonic mesoderm [Tsang et al., 2001], indicating that $L h x 1$ might be involved in correctly localizing PGCs in the epiblast. To address the role of $L h x 1$ in germ cell specification and migration, Meox2Cre lines were used where $L h x 1$ was floxed in epiblast derivatives. In these animals, during initial development, the PGCs are localized properly to the definitive endoderm of the posterior gut, but they depart prematurely and disperse to the adjacent mesenchyme [Tanaka et al.,
2010], indicating that $L h x 1$ regulated the timing of PGC migration in the developing embryos. Whether this is a cell-autonomous activity of LHX1 in the germ cells or due to disrupted signaling activities in the neighboring cells is currently unclear. Nevertheless, based on the data of mouse genetics, it can be concluded that $L h x 1$ is necessary for the differentiation of progenitor cells in the müllerian ducts and also in the regulation of timely PGC migration in the mouse.

\section{LIM Homeobox Gene 9 (Lhx9)}

$L h x 9$ is evolutionarily conserved and expressed in the central nervous system, heart, limb bud, and gonads [Bertuzzi et al., 1999; Rétaux et al., 1999; Birk et al., 2000; Tzchori et al., 2009; Yamazaki et al., 2015]. Urogenital ridge expression of $\operatorname{Lh} x 9$ is highly conserved during vertebrate gonad development. It is detected in the gonads of rainbow trout [Baron et al., 2005], chinese tongue sole (Cynoglossus semileavis) [Zhu et al., 2019], red-eared slider turtle [Bieser et al., 2013], frog (Rana rugosa) [Oshima et al., 2007], chicken [Oréal et al., 2002; Feng et al., 2007], 
adult Chinese giant salamander (Andrias davidianus) [Hu et al., 2016], rat [Mazaud et al., 2002], and the mouse [Birk et al., 2000]. In the developing mouse embryos at 15 days post coitum, $\operatorname{Lh} x 9$ is moderately expressed only in gonads of both sexes and no expression is seen in the mesonephric or paramesonephric ducts (Fig. 1).

$L h x 9$ is indispensable for gonad development as is evident from studies in $L h x 9^{-/-}$mice. Mice heterozygous for the $\operatorname{Lh} x 9$ mutation are normal and fertile. The homozygous mutant offspring (irrespective of the chromosomal constituent whether XX or XY) are phenotypically female (despite being Sry positive) and are sterile [Birk et al., 2000]. The adult $L h x 9^{-/-}$animals lack gonads, the $\mathrm{XX}$ mice have atrophic müllerian ducts, and the XY mice do not have accessory sex organs indicative of the absence of gonadal hormone activity. Although the embryonic central nervous system, limbs, and pancreas normally express $L h x 9$, no gross abnormalities in these structures were reported in $L h x 9^{-/-}$mice [Birk et al., 2000]. These observations imply that $L h x 9$ has an indispensable role in the development and/or differentiation of the genital ridges in mice.

$L h x 9$ appears to play a role in developing gonads after the formation of the genital ridges. At E11.5, the $\operatorname{Lh} x 9^{-/-}$ and wild-type urogenital ridges were morphologically indistinguishable, but the ridge completely disappears by E13.5. This is not due to any defects in germ cell migration but the failure of the somatic cells to proliferate [Birk et al., 2000]. Lhx9 is required for proper expansion of somatic cell populations that are precursors of the supporting lineage (Sertoli and granulosa cells). In the $L h x 9^{-/-}$ embryonic gonads, Wt1, Lhxl, and Daxl genes are correctly expressed, indicating that the genital ridges are formed appropriately; however, Sf1 (marker of somatic cell precursor) expression is markedly reduced [Birk et al., 2000]. These observations suggest that $\operatorname{Lh} x 9$ is not required for the specification of the urogenital ridge but necessary for its further development into the bipotential gonads.

The LHX9 expressing cells are the progenitors of the somatic cell lineage in the mouse gonad. Mice lacking Numb genes (Numb1 and Numb2) have a marked reduction in numbers of Sertoli cells, absence of Leydig cells, and an uncontrolled expansion of LHX9-positive cells from the overlying coelomic epithelium [Lin et al., 2017]. Similar to the XY gonads, the Numb mutant XX gonads also have reduced numbers of the differentiated cell types and expansion of LHX9 positive cells in the celomic epithelium [Lin et al., 2017]. These results imply that $\operatorname{Lh} x 9$ specifies the multipotent progenitors in both sexes.

LIM-HD Genes in Gonads
In the Leydig cells, $\operatorname{Lh} x 9$ is required for testosterone biosynthesis. It is shown in Leydig cell lines that $L h x 9$ is targeted to ubiquitin-mediated proteasome degradation by Smad ubiquitylation regulatory factor 1 (Smurf1), an E3 ubiquitin ligase [Hu et al., 2018]. Interestingly, elevated Smurf1 decreases the level of $L h x 9$ and inhibits $S f 1$ transactivation, and conversely downregulation of Smurf 1 increases the levels of LHX9 protein and enhance testosterone biosynthesis in vitro [Hu et al., 2018]. Furthermore, mice knockouts for Smurf1 have elevated levels of LHX9, increased steroidogenesis in Leydig cells, and higher levels of serum testosterone [Hu et al., 2018]. These findings indicate that a finely regulated activity of LHX9 ubiquitylation is required in the Leydig cells to maintain SF1 levels and regulation of steroidogenesis.

\section{LIM Homeobox Gene 8 (Lhx8)}

In the mouse, $L h x 8$ is expressed in oral mesenchyme, developing palate, teeth [Zhao et al., 1999], cholinergic neurons of forebrains [Zhao et al., 2003], and gonads [Pangas et al., 2006]. In the developing mouse gonads, Lhx8 is exclusively expressed in female germ cells from E13.5 onwards [Pangas et al., 2006]. Germ cell-specific expression of $L h x 8$ is conserved in mice, bovine, and humans [Choi et al., 2008; White et al., 2012; Fu et al., 2016]. The nuclear expression of LHX8 in oogonia increases with the advancement of embryonic development that is from E13.5 to day 14 postpartum which is temporally correlated with the activation of primordial follicles [Choi et al., 2008]. This increased expression of LHX8 is due to demethylation of $3^{\prime}$ UTR of $L h x 8$ and high acetylation of histone H3 [Zhang et al., 2012]. In the mouse gonads at 15 days post coitum, $L h x 8 \mathrm{mRNA}$ is strongly detected in the XX gonads with no expression in the $\mathrm{XY}$ gonads (Fig. 1).

Mice with a targeted disruption of $\operatorname{Lh} x 8$ have normal ovarian development but have progressive loss of oocytes by 7 days postpartum, and subsequently, the null female mice are infertile [Choi et al., 2008]. The progressive loss of germ cells is due to increased apoptosis and downregulation of oocyte pro-survival factors like Kit and KitL in Lh $x 8^{-/-}$ovaries [Choi et al., 2008]. However, testes of adult $L h x 8^{-/-}$are similar to the wild type, and the males are fertile albeit have reduced litter size [Choi et al., 2008]. These results indicate that $L h x 8$ is essential for oocyte development and differentiation but is dispensable for spermatogenesis. To study the role of $L h x 8$ postnatally, conditional ablation of $L h x 8$ in oocytes using Gdf9-Cre was done. $L h x 8$ inactivation postnatally leads to premature massive oocyte activation. This premature oocyte activa- 
tion was dissociated from somatic cell transformation and was followed by oocyte death, resulting in infertility [Ren et al., 2015]. Functionally, LHX8 regulates the expression of multiple oogenesis-related genes like Nobox and Figla which have crucial roles in primordial follicle activation and secondary follicle transition [Choi et al., 2008; Ren et al., 2015; Fu et al., 2016; Wang et al., 2020]. In addition to its role in the regulation of transcription of oocyte-specific genes, LHX8 physically binds to the promoter and represses the expression of $\operatorname{Lin} 28 a$, which is a regulator of the AKT/mTOR pathway [Ren et al., 2015]. Interestingly, the PI3K-AKT-mTORC1 pathways within oocytes are required for primordial follicle activation [Ren et al., 2015; Chen et al., 2020]. These results suggest that LHX8 transcriptionally regulates the entire network of factors that are involved in primordial follicle activation and primary follicle transition.

Beyond its roles as a transcription factor, LHX8 protein is also a part of the hub of a multimeric protein-protein network of oocyte-specific genes. It was observed that LHX8, FIGLA, NOBOX, SOHLH1, and SOHLH2 form a multiprotein regulatory complex in the ovary [Wang et al., 2020]. Interestingly, the LHX8-FIGLA interaction is conserved in murine [Wang et al., 2020], cattle, bovine, and rainbow trout [Fu et al., 2016] and is dependent on the LIM domain of LHX8 [Fu et al., 2016].

Along with its role in primordial follicle activation, Lhx8 may also have a role in the regulation of meiosis. Although the germ cells in the $L h x 8$ knockout mice enter meiosis on time (E13.5), in $L h x 8$ knockout ovaries there is a persistent expression of Stra8 in the postnatal ovary [Choi et al., 2008]. It is reported that germ cells must expressStra 8 only once to initiate the premeiotic DNA duplication [Baltus et al., 2006], after which Stra 8 has to be suppressed in the meiotic oogonia [Soh et al., 2015]. Since Stra 8 expression persists in the germ cells of $L h x 8^{-/-}$mice, it is plausible that $L h x 8$ is a gatekeeper to ensure that each germ cell is exposed to a Stra8 peak once only. It will be of interest to explore the roles of $L h x 8$ in the timely regulation of meiosis progression and its arrest in the developing ovaries.

\section{Co-Regulators of LIM-HD Proteins}

LIM-HD proteins interact intra- and inter-molecularly to execute their functional activity [Curtiss and Heilig, 1998]. LIM only (LMO) and LIM domain-binding (LDB) proteins play a crucial role in the regulation of LIM-HD protein activity by controlling their shuttling between cy- toplasm and the nucleus thereby augment the transcriptional activities [Matthews and Visvader, 2003; Subramanian et al., 2003; Matthews et al., 2009; Sang et al., 2014]. The levels and stoichiometry of these LMOs and LDBs in cells are tightly regulated and are the determinants of the spatial and temporal function of LIM-HD genes [Sang et al., 2014; Liu and Dean, 2019].

In its active state, the tandem LIM domains of LIMHD proteins bind to the LDB through the LIM interaction domain (LID) near the C-terminus that enables the formation of tetrameric or higher-order complexes and exposes the homeodomain of LIM-HD, allowing binding to the DNA in the promoter or enhancer elements thereby regulating gene transcription (Fig. 2). The LMO proteins can regulate the transcriptional activity of LIM-HD proteins by competing for binding to LDB (Fig. 2). This displaces the LIM-HD proteins from the complex, releasing them from the DNA, and the LIM-HD proteins are subjected to degradation thereby terminating their activity. In some instances, one of the LID of the LDB proteins interacts with LMO, while the other interacts with LIMHD thereby limiting the availability of the LIM-HD molecules at the gene promoter/enhancer region allowing a dose-dependent modulation of gene transcription (Fig. 2). While this model is largely based on observations in drosophila, similar regulation is also known in mammals [Monahan et al., 2019; Kinare et al., 2020]. Thus, for a complete understanding of the roles of LIM-HDs, it is important to explore the status of LMOs and LDBs in the developing systems.

$L d b$ genes are highly conserved from worm to man, sharing approximately $95 \%$ of sequence similarity although their numbers vary across species [Matthews and Visvader, 2003; Liu and Dean, 2019]. In mice, $L d b 1$ and $L d b 2$ are highly conserved, and $L d b 1$ is ubiquitously expressed in many tissues whereas $L d b 2$ expression is tissue-specific throughout mouse embryogenesis [Visvader et al., 1997; Bulchand et al., 2003; Matthews and Visvader, 2003; Ostendorff et al., 2006; Matthews et al., 2008; Leone et al., 2017]. However, their expression profiles and role in the context of gonad development are not yet explored.

$L d b 1^{-/-}$embryos are embryonic lethal and die around E9.5. $L d b 1^{-/-}$mice display a pleiotropic phenotype; there is a lack of heart anlage, truncated head structures, and posterior axis duplication in $40 \%$ of the mutants [Mukhopadhyay et al., 2003]. Ldb2 ${ }^{-/-}$mice do not exhibit an obvious phenotype possibly due to the redundant function of $L d b 2$ and $L d b 1$ [Mukhopadhyay et al., 2003; Narkis et al., 2012; Gueta et al., 2016; Leone et al., 2017]. 


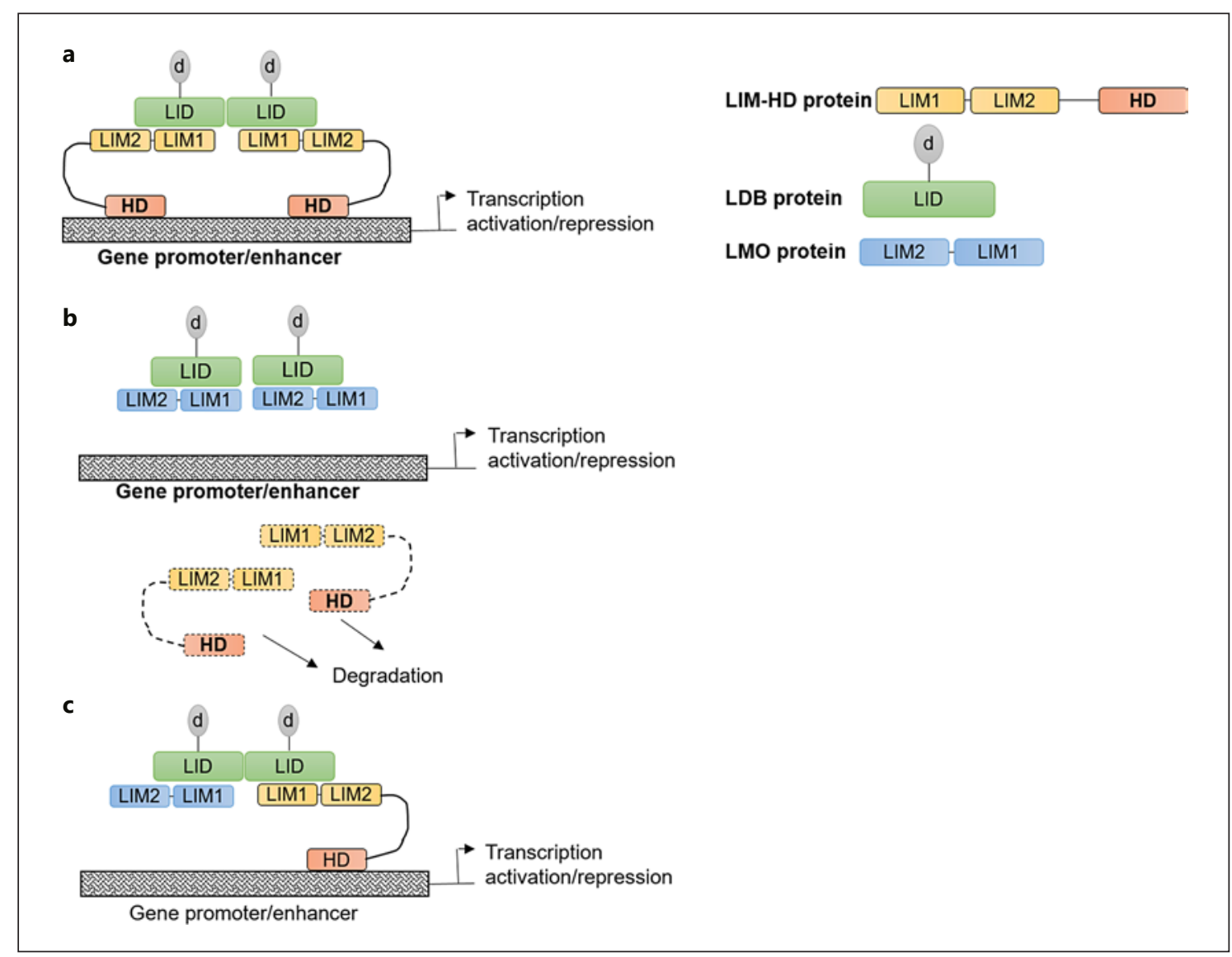

Fig. 2. A proposed model for the regulation of LIM-HD protein activity by LDB and LMOs. a In the active state dimerization (d) of the LIM interaction domain (LID) of LDB allows the formation of tetrameric or higher-order protein complexes with LIM-HD, and the homeodomain is exposed for DNA binding on promoters/ enhancers to regulate gene transcription. b For inactivation the LMOs compete with the LIM-HD proteins and bind to the LDBs.

LMOs, by their virtue of regulating LIM-HD activity, also directly play roles in the regulation of cell-fate determination and tissue development [Sang et al., 2014]. They regulate gene transcription by functioning as "linker" or "scaffolding" proteins with a remarkable potential to mediate protein-protein interactions (Fig. 2). LMO proteins have been the best explored for their roles in tumorigenesis and cell proliferation [Zheng and Zhao, 2007; Matthews et al., 2013; Chambers and Rabbitts, 2015].

Amongst the LMO genes, $L m o 4$ is expressed in the developing mouse gonads in a sexually dimorphic manner. Munger et al. [2013] reported higher expression of Lmo4 in the XY gonadal primordia from E11.5 until E15.5 as compared to XX. To investigate the role of $L m o 4$, in vitro primary gonad cultures from E12.5 XY embryos were
This releases the LDBs from the LIM-HD which are eventually degraded bringing about alterations in the LIM-HD mediated DNA transcription. c In other states, one of the LIM-HD may bind the LDB dimer while the other is occupied by LMO, thereby limiting the availability of the LIM-HD molecules at the gene promoter/ enhancer and modulating gene transcription. Adapted from Subramanian et al. [2003].

transduced with lentivirus containing shRNA for Lmo4 and analyzed for expression of Sertoli cell markers. The results revealed that loss of $L m o 4$ led to a reduction in expression of Sertoli cell-specific genes $S f 1$, Sox 9 , Fgf 9 , and Col9a3, implying its involvement in testis differentiation [Munger et al., 2013]. While the partners of LMO4 protein in developing gonads are not known, in the brain of mice and chicken, an inverse correlation in expression of Lhx 9 and Lmo4 is observed, suggesting that $L h x 9$ activity is regulated by Lmo4 [Abellán et al., 2014]. Thus it is tempting to speculate that the transition of somatic precursors to the supporting lineage of the testis may also require a balanced interaction between LHX9 and LMO4 It will be of interest to explore these interactions to have a mechanistic insight into factors that govern the transi- 
Table 1. LIM-HD genes and disorders of sex development

\begin{tabular}{llll}
\hline $\begin{array}{l}\text { LIM-HD } \\
\text { Gene }\end{array}$ & $\begin{array}{l}\text { Cytogenetic } \\
\text { band }\end{array}$ & Associated DSD & References \\
\hline LHX1 & $17 q 12$ & $\begin{array}{l}\text { Mayer-Rokitansky-Kuster-Hauser (MRKH) syndrome and } \\
\text { incomplete müllerian fusion (IMF), müllerian duct aplasia (MDA) }\end{array}$ & $\begin{array}{l}\text { Ledig et al. [2012, 2018]; Xia et al. [2012]; } \\
\text { Sandbacka et al. [2013]; Zhang et al. [2017] }\end{array}$ \\
\hline LHX8 & 1 p31.1 & No association with premature ovarian failure (POF) & Qin et al. [2008]; Jeon et al. [2010] \\
\hline LHX9 & 1 q31.3 & 46,XY DSD & Wang et al. [2018]; Kunitomo et al. [2020] \\
\hline LHX3 & $9 q 34.3$ & $\begin{array}{l}\text { Combined pituitary hormone deficiency (CPHD) and } \\
\text { hypogonadotropic hypogonadism }\end{array}$ & Fang et al. [2016] \\
\hline LHX4 & 1 q25.2 & $\begin{array}{l}\text { Combined pituitary hormone deficiency (CPHD) and } \\
\text { hypogonadotropic hypogonadism }\end{array}$ & Fang et al. [2016]; Cohen et. [2017] \\
\hline
\end{tabular}

Fig. 3. Expression of $L H X 1, L H X 8$, and LHX9 mRNA in the adult human reproductive system. Consensus normalized expression data from Human Protein Atlas (https://www.proteinatlas.org/;accessed March 15, 2021). Heat maps were generated using Morpheus software (https:// software.broadinstitute.org/morpheus/).

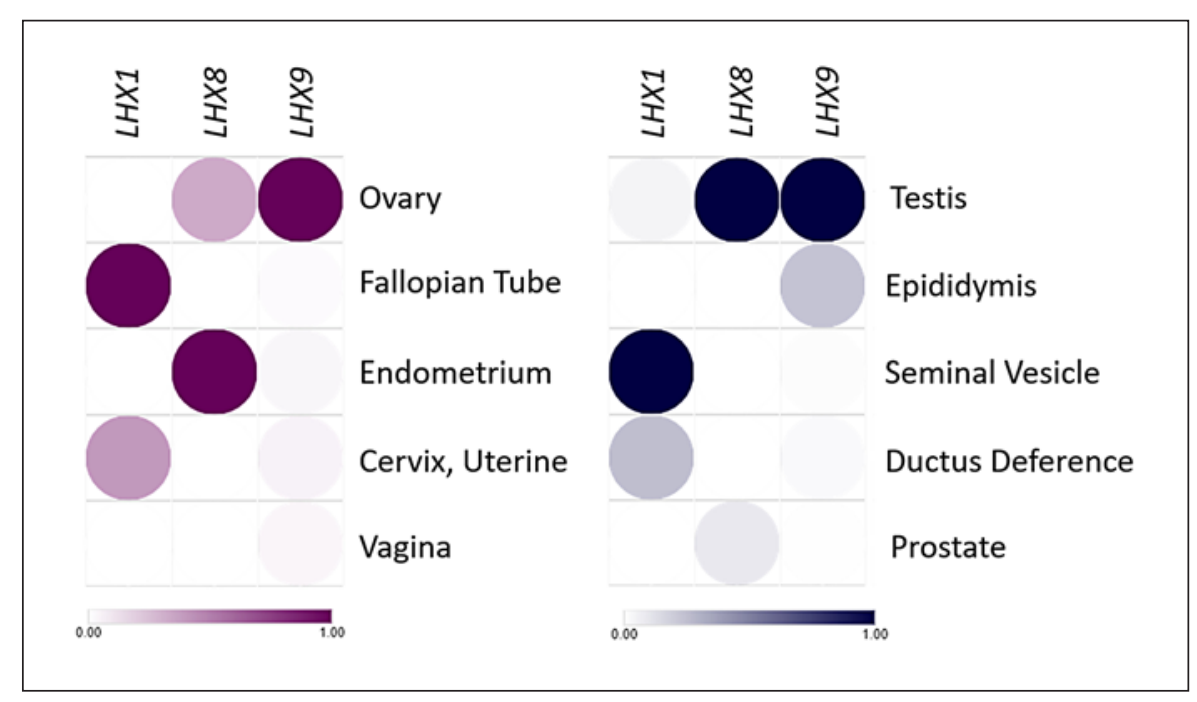

tion of somatic precursors to the differentiated forms in the developing XY gonads. Beyond the testis, single-cell RNAseq profiling of mouse germ cells identified $\mathrm{Lmo}_{4}$ to be enriched during early meiotic stages [Zhao et al., 2020]. Thus the roles of Lmo4 genes in gonad development need to be explored in depth.

\section{LIM-HD Genes in Disorders of Sex Development}

The roles of LIM-HD genes in the development of the reproductive system prompted us to look at the involvement of these genes in patients with DSD, and this is summarized in Table 1. In humans, $L H X 1 \mathrm{mRNA}$ is expressed in the adult fallopian tube, cervix, and uterus, along with the seminal vesicles and ductus deference (Fig. 3). Considering the expression and role of $L h x 1$ in müllerian duct development in the mouse, its involvement as a candidate gene for Mayer-Rokitansky-Kuster-Hauser (MRKH) syndrome has been extensively investigated. MRKH syndrome is characterized by congenital aplasia of the uterus and upper two-third part of the vagina with normal ovarian development and functions in women with a 46,XX karyotype. $L H X 1$ is mapped to chromosome $17 \mathrm{q} 12$ in humans [Grafodatskaya et al., 2007], and deletion of a 1.7Mb locus at $17 \mathrm{q} 12$ encompassing the $L H X 1$ gene was found in females with müllerian duct aplasia (MDA) [Cheroki et al., 2008; Bernardini et al., 2009; Sandbacka et al., 2013]. Another study reported a deletion of a 1.2-1.7 $\mathrm{Mb}$ region on $17 \mathrm{q} 12$ encompassing the $L H X 1$ gene in $6 \%$ of women with MRKH syndrome [Ledig et al., 2018]. Besides large deletions, frameshift and missense mutations in LHX1 are also reported in patients with MRKH syndrome. Sequence analysis of $L H X 1$ in a large cohort of 
MRKH patients identified a heterozygous frameshift mutation (c.25dup; p.Arg9LysfsX25), resulting in a premature stop codon [Ledig et al., 2012]. Zhang et al. [2017] using whole-exome sequencing analysis reported a novel missense mutation in LHX1 (NM_005568: c.G1108A, p.A370T) in a woman with MRKH syndrome. Luciferase assay showed that the mutation altered the transcriptional activity of $L H X 1$ and affected the expression of its target gene GSC. However, LHX1 mutations are not detected in the coding region in patients with structural müllerian duct abnormalities such as uterine agenesis and incomplete müllerian fusion [Xia et al., 2012]. A 12-bp deletion (c.1070-1081del) in exon 5 resulting in the loss of 4 amino acids (p.357-360del Pro-Glu-Pro-Ser) of LHX1 was identified in a patient with incomplete müllerian fusion [Xia et al., 2012]. This deletion is in the 3rd low complexity region and does not change the grand average of hydrophobicity of LHX1 [Xia et al., 2012]. Hence, the significance of this deletion and the associated phenotype is yet not clear. These results imply that akin to the mouse, loss of $L H X 1$ in humans leads to extreme forms of müllerian duct abnormalities like MKRH syndrome.

In humans, $L H X 9$ is mapped to chromosome 1q31q32, and the mRNA is expressed in the adult testis, ovaries, and the epididymis (Fig. 3). Akin to mice, LHX9 is expressed in the bipotential gonad precursors during differentiation of human embryonic and induced pluripotent stem cells [Sepponen et al., 2017; Knarston et al., 2020]. Considering its indispensable role in early gonad development and as mice knockout for $\operatorname{Lh} x 9$ do not have gross developmental anomalies, it is considered to be one of the strong candidates of non-syndromic isolated human DSD. However, screening of human patients with gonadal disorders including bilateral gonadal agenesis did not identify mutations in the coding region of the LHX9 gene [Ottolenghi et al., 2001]. Recently, 2 different variants in $L H X 9$ were identified in 2 patients with $46, \mathrm{XY}$ DSD [Wang et al., 2018]. Patient 1 presented with testicular regression and had a sequence variation in the LHX9 gene. Patient 2 manifested with micropenis and hypospadias and had an $L H X 9$ variation and a heterozygous mutation in the SRD5A2 (steroid 5-alpha reductase 2) gene. It is plausible that in this case, the LHX9 variant combined with the heterozygous mutation in SRD5A2 might synergize to produce the phenotypic heterogeneity of 5a-reductase type 2 like defects [Wang et al., 2018]. In another study, a de novo heterozygous missense variant in LHX9 was identified in a phenotypic female with a 46,XY karyotype and finger and toe abnormalities [Kunitomo et al., 2020]. However, in absence of any func- tional validation of the $L H X 9$ gene variants in both these reports, it is difficult to draw any conclusions about the involvement of LHX9 in causing DSDs. In summary, although based on mouse phenotype, $L H X 9$ is a strong candidate for DSDs, but mutations (if any) in the human LHX9 gene are rare.

Human LHX8 is mapped to $1 \mathrm{p} 31.1$ and is expressed in the adult ovary, endometrium, and to a lesser extent in the prostate (Fig. 3). Considering the mouse phenotype and its expression in humans, LHX8 is considered a strong candidate gene for premature ovarian failure (POF). LHX8 gene sequencing was first reported in 95 Caucasian women with POF. Two novel single nucleotide polymorphisms (SNPs) in intron 3 (c.769+10G $>$ T) and the $3^{\prime}$ untranslated region (c.1787A $>\mathrm{G})$ of the $L H X 8$ gene were discovered [Qin et al., 2008]. In another study, 96 women with POF from a Korean population were screened. Sequence analysis revealed 4 known SNPs, 2 novel SNPs in intron $4(\mathrm{c} .114+99 \mathrm{C}>\mathrm{A}),(\mathrm{c} .114+100 \mathrm{C}>\mathrm{A})$ and 1 in intron 6 (c.390+77C > G) were identified [Jeon et al., 2010]. However, these variants are polymorphic as they are present at almost identical frequencies in control women and therefore unlikely to be causative of POF [Qin et al., 2008; Jeon et al., 2010; Zhou et al., 2015]. No other studies have investigated the $L H X 8$ gene in the context of POF or other germ cell-related abnormalities in humans.

Mutations in some LHX3 and LHX4 cause combined pituitary hormone deficiency (CPHD) which is associated with delayed or absent puberty. $L h x 3$ and $L h x 4$ are expressed in the pituitary primordium (Rathke's pouch) of mouse and essential for pituitary development in mouse and human [Fang et al., 2016]. Patients with mutations in either LHX3 or LHX4 genes suffer from CPHD, and a subset of these patients have gonadotropin deficiency and absent or delayed puberty [Fang et al., 2016; Cohen et al., 2017; Butz et al., 2021]. Kallmann syndrome is characterized by delayed or absent puberty and an impaired sense of smell due to a failure in development and/or migration of the gonadotropin releasing hormone $(\mathrm{GnRH})$ neurons in the fetal brain. Conditional inactivation of $L h \times 2$ in the mouse olfactory sensory neurons results in compromised development of the olfactory sensory nerve, and the GnRH neurons are unable to continue their journey to the hypothalamus. Both male and female mice develop hypogonadism and do not undergo puberty similar to that seen in Kallmann syndrome [Berghard et al., 2012; Chou and Tole, 2019]. However, LHX2 gene sequences are not analyzed in patients with Kallmann syndrome.

To conclude, mutations in the LHX1 gene are associated with MKRH, while deletions or mutations in the 

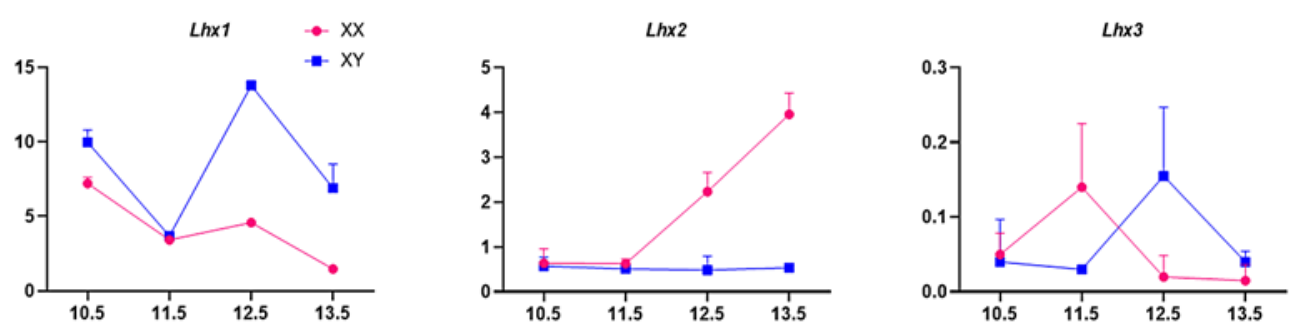

Lhx4
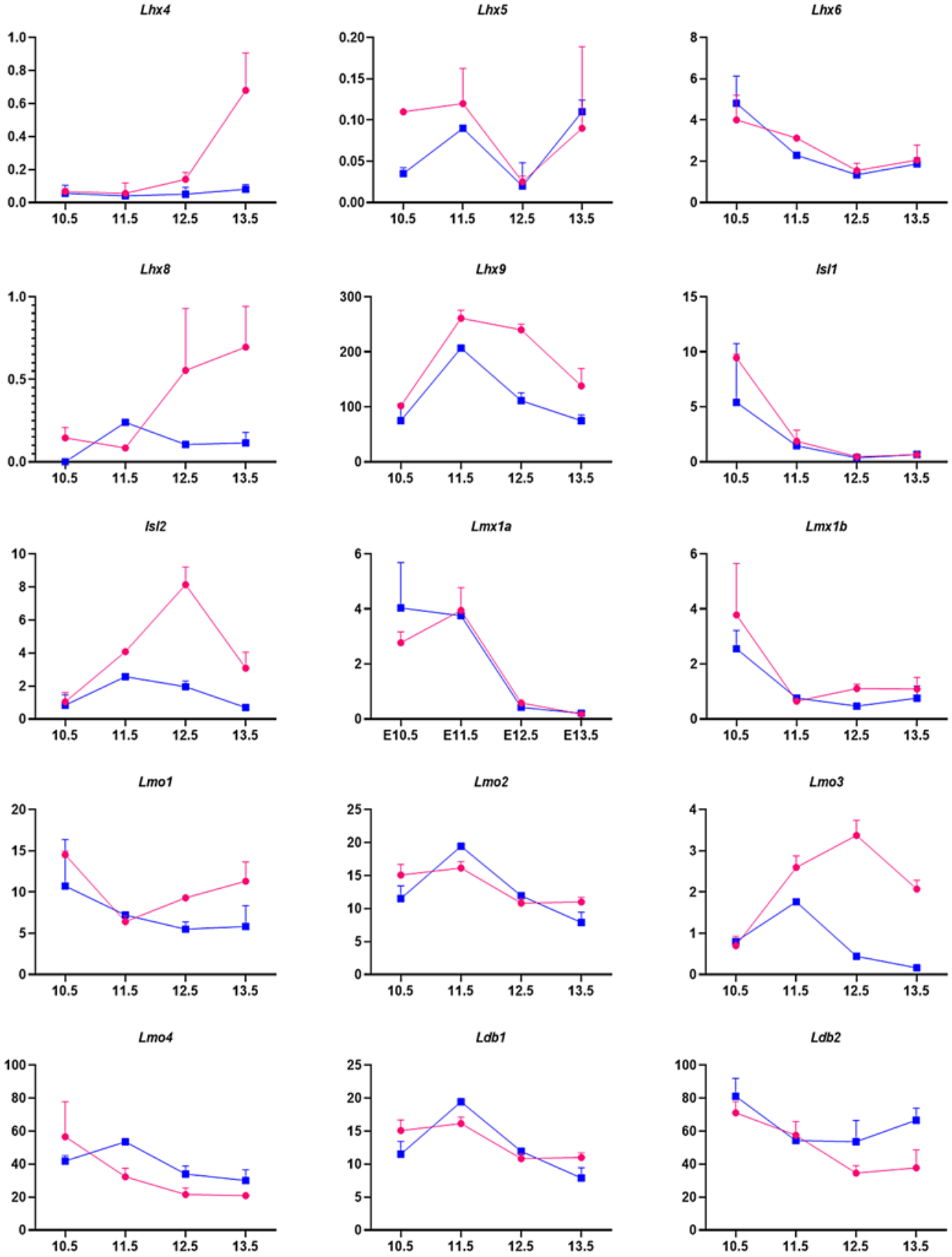

4 
LHX3 and LHX4 genes are associated with absence or delayed puberty due to CPHD. Whether genetic alterations in other LIM-HD genes or their co-regulators are associated with DSD is yet not known.

\section{The Landscape of LIM-HD Genes and Their Co- Regulators in the Developing Mouse Gonads}

The role of LIM-HD genes $L h x 1, L h x 8$, and $L h x 9$ in reproductive development compelled us to ask whether other members of the LIM-HD family are expressed in developing gonads. Therefore, we analyzed bulk RNAseq data of mouse developing gonads from E10.5 to E13.5 [Zhao et al., 2018]. In this dataset, the expression of $\operatorname{Lh} x 8$ was female dominant and Lmo4 was male dominant as reported previously [Pangas et al., 2006; Munger et al., 2013] and hence validating the dataset. As evident, the mRNA levels of most of the LIM-HD, Lmo, and $L d b$ genes were altered temporally in the developing gonads. The mRNA of some genes (Lhx6, Isl1, Lmxla, Lmx $1 b$, and $L d b 2)$ were higher at the initial stages (E10.5) and reduced as the gonad took the sexual fate, indicating their roles in the early steps of gonad development (Fig. 4). In contrast, the expression of some genes ( $L h x 2, L h x 4, \operatorname{Lhx} 8, L m o 3)$ peaked after E11.5, indicating their roles at later stages of development. Some genes (Lhx1,Lhx3,Lhx5, Lhx9, Ils2, $L d b 1$ ) fluctuated through the course of development. Interestingly, several genes were also expressed in a sexually dimorphic manner. These include $\operatorname{Lh} x 2, \operatorname{Lh} x 4, \operatorname{Lh} x 8$, Lhx 9, Isl2, Lmo 1, Lmo3, which are generally expressed in a female dominant manner, and $L h x 1$ and Lmo4, which have a male-dominant expression (Fig. 4). Lhx3 had a very interesting pattern of expression because it is female dominant at E11.5 but becomes male dominant at E12.5 with identical expression levels in both sexes at other time points. However, the expression of $L h x 3$ and $L h x 5$ is at

Fig. 4. Expression atlas of LIM-HD family members and their coregulators in the mouse gonads during the window of sex determination. The data on mRNA levels expressed out of 13 genes of LIM-HD family ( $L h x 1-L h \times 9$, Isl1-2, Lmx $1 a-1 b), 4$ LIM only (Lmo $1-4)$, and 2 LIM domain-binding ( $L d b 1-2)$ in XX and XY gonads during the window of sex determination (E10.5-E13.5) was extracted from the publicly available bulk RNAseq data of mouse gonads [Zhao et al., 2018; accession number: SRP076584]. In each graph, the mean TPM (transcript per million) value along with standard deviation ( $n=3$ for each sex at each time point) is plotted on the $y$ axis and the day of gonad development (E10.5-13.5) is plotted on the $x$ axis. Blue line is for XY whereas pink line is for XX gonads.

LIM-HD Genes in Gonads very low abundance and the variations could be possibly an experimental artefact. Although we await experimental validation for protein expression of these genes, based on the expression map, we propose that beyond the serendipitously discovered roles of $\operatorname{Lh} \times 1, \operatorname{Lh} \times 9$, and $\operatorname{Lh} \times 8$, the roles of other LIM-HD gene family members and their regulators must be systematically investigated in the process of gonad development.

\section{Summary}

Since the discovery of the sex-determining gene Sry, it is now evident that gonad development and its differentiation to an ovary or testis is a complex process governed by an intricate network of regulatory genes. As discussed, 3 LIM-HD genes are reported to have crucial roles in reproductive tissue development. A preliminary transcript map of the Lim-homeobox, Lmo, and $L d b$ genes shows that the expression of other members is dynamically regulated in the developing gonads, and some are also sexually dimorphic during sex determination. With the single-cell RNAseq technologies being increasingly applied to developing tissues including the gonads, we should develop the spatio-temporal maps of these genes to define their specific roles in the gonads. It will be imperative to see if these expression profiles are evolutionarily conserved, and the effects of targeted disruption of these genes should yield insights into the hitherto unexplored roles of LIM-HD genes in sexual development. However, gene knockout and/or knockdown approaches for the LIM-HD genes in mice are not going to be straightforward as they have multiple roles in other tissues and their knockouts are often embryonically lethal. Further, like the homeobox gene family, the LIM-HD family is also full of backups and functional redundancy making it harder to define the roles of individual genes.

Some interesting questions to be answered regarding the role of LIM-HD genes in the developing gonads would be: (1) Like that seen in the developing brain, do the LIMHD genes in the gonads form a unique "LIM code" that is, combinatorial expression of LIM genes that specify cell identities? (2) Are the LIM-HD genes nodes of the known networks or hubs in the genetic orchestra of gonad development and sex determination? (3) Are some human DSD caused due to mutation in the LIM-HD genes?

This review could serve as a guide for future research choices in these directions for improving our understanding of gonad development and processes involved in sex determination and differentiation. 


\section{Acknowledgments}

N.S. is thankful to ICMR-Senior Research Fellowship. D.S. is thankful to UGC for Junior Research Fellowship. The manuscript bears the NIRRH ID: Rev/1058/04-2021.

\section{Conflict of Interest Statement}

The authors declare no conflict of interest.

\section{Funding Sources}

D.M. laboratory is funded by grants from the Indian Council of Medical Research (ICMR) and the Department of Biotechnology (DBT) Government of India under the Grant ID: BT/PR10368/ MED/97/223/2014.

\section{Author Contributions}

D.M. and N.S. conceptualized and wrote the manuscript. D.S. analyzed the RNAseq dataset and made the figures. All authors read and edited the manuscript.

\section{References}

Abellán A, Desfilis E, Medina L. Combinatorial expression of Lef1, Lhx2, Lhx5, Lhx9, Lmo3, Lmo4, and Prox1 helps to identify comparable subdivisions in the developing hippocampal formation of mouse and chicken. Front Neuroanat. 2014;8:59-22.

Arboleda VA, Sandberg DE, Vilain E. DSDs: Genetics, underlying pathologies and psychosexual differentiation. Nat Rev Endocrinol. 2014;10:603-15.

Ashary N, Laheri S, Modi D. Homeobox genes in endometrium: From development to decidualization. Int J Dev Biol. 2020;64:227-47.

Bach I. The LIM domain: Regulation by association. Mech Dev. 2000;91(1-2):5-17.

Baltus AE, Menke DB, Hu YC, Goodheart ML, Carpenter AE, De Rooij DG, et al. In germ cells of mouse embryonic ovaries, the decision to enter meiosis precedes premeiotic DNA replication. Nat Genet. 2006;38:14304.: In

Banerjee-Basu S, Baxevanis AD. Molecular evolution of the homeodomain family of transcription factors. Nucleic Acids Res. 2001;29: 3258-69.

Barnes JD, Crosby JL, Jones CM, Wright CV, Hogan BL. Embryonic expression of Lim-1, the mouse homolog of Xenopus XLim-1, suggests a role in lateral mesoderm differentiation and neurogenesis. Dev Biol. 1994;161:168-78.

Baron D, Houlgatte R, Fostier A, Guiguen Y. Large-scale temporal gene expression profiling during gonadal differentiation and early gametogenesis in rainbow trout. Biol Reprod. 2005;73:959-66.

Bashamboo A, Eozenou C, Rojo S, McElreavey K. Anomalies in human sex determination provide unique insights into the complex genetic interactions of early gonad development. Clin Genet. 2017;91:143-56.

Berghard A, Hägglund AC, Bohm S, Carlsson L. Lhx2-dependent specification of olfactory sensory neurons is required for successful integration of olfactory, vomeronasal, and GnRH neurons. FASEB J. 2012;26:3464-72.
Bernardini L, Gimelli S, Gervasini C, Carella M, Baban A, Frontino G, et al. Recurrent microdeletion at $17 \mathrm{q} 12$ as a cause of Mayer-Rokitansky-Kuster-Hauser (MRKH) syndrome: Two case reports. Orphanet J Rare Dis. 2009; 4:1-6.

Bertuzzi S, Porter FD, Pitts A, Kumar M, Agulnick A, Wassif C, et al. Characterization of Lhx9, a novel LIM/homeobox gene expressed by the pioneer neurons in the mouse cerebral cortex. Mech Dev. 1999;81:193-8.

Biason-Lauber A. WNT4, RSPO1, and FOXL2 in sex development. Semin Reprod Med. 2012; 30:387-95

Bieser KL, Wibbels T, Mourad G, Paladino F. The cloning and expression analysis of Lhx 9 during gonadal sex differentiation in the redeared slider turtle, Trachemys scripta, a species with temperature-dependent sex determination. J Exp Zool B Mol Dev Evol. 2013; 320:238-46.

Birk OS, Casiano DE, Wassif CA, Cogliati T, Zhao L, Zhao Y, et al. The LIM homeobox gene Lhx9 is essential for mouse gonad formation. Nature. 2000;403:909-13.

Bulchand S, Subramanian L, Tole S. Dynamic spatiotemporal expression of LIM genes and cofactors in the embryonic and postnatal cerebral cortex. Dev Dyn. 2003;226:460-9.

Bürglin TR, Affolter M. Homeodomain proteins: an update. Chromosoma. 2016;125:497-521.

Butz H, Nyírő G, Kurucz PA, Likó I, Patócs A. Molecular genetic diagnostics of hypogonadotropic hypogonadism: from panel design towards result interpretation in clinical practice. Hum Genet. 2021;140(1):113-34.

Chambers J, Rabbitts TH. LMO2 at 25 years: A paradigm of chromosomal translocation proteins. Open Biol. 2015;5:150062-15.

Chassot AA, Gillot I, Chaboissier MC. R-spondin1, WNT4, and the CTNNB1 signaling pathway: Strict control over ovarian differentiation. Reproduction. 2014;148:R97-110.

Chen Y, Liu Y, Gong Q, Lai J, Song M, Du J, et al. Gonadal transcriptome sequencing of the critically endangered Acipenser dabryanus to discover candidate sex-related genes. PeerJ. 2018;6:e5389-24.
Chen Y, Yang W, Shi X, Zhang C, Song G, Huang D. The factors and pathways regulating the activation of mammalian primordial follicles in vivo. Front Cell Dev Biol. 2020;8:57570611.

Cheroki C, Krepischi-Santos AC, Szuhai K, Brenner V, Kim CA, Otto PA, et al. Genomic imbalances associated with Müllerian aplasia. J Med Genet. 2008;45:228-32.

Choi Y, Ballow DJ, Xin Y, Rajkovic A. Lim homeobox gene, lhx 8 , is essential for mouse oocyte differentiation and survival. Biol Reprod. 2008;79:442-9.

Chou SJ, Tole S. Lhx2, an evolutionarily conserved, multifunctional regulator of forebrain development. Brain Res. 2019;1705:1-14.

Clarkson MJ, Harley VR. Sex with two SOX on: SRY and SOX9 in testis development. Trends Endocrinol Metab. 2002;13:106-11.

Cohen E, Maghnie M, Collot N, Leger J, Dastot F, Polak M, et al. Contribution of LHX4 mutations to pituitary deficits in a cohort of 417 unrelated patients. J Clin Endocrinol Metab. 2017;102:290-301.

Cunha GR, Robboy SJ, Kurita T, Isaacson D, Shen J, Cao M, et al. Development of the human female reproductive tract. Differentiation. 2018;103:46-65.

Curtiss J, Heilig JS. DeLIMiting development. Bioessays. 1998;20(1):58-69.

Dong WL, Tan FQ, Yang WX. Wnt signaling in testis development: Unnecessary or essential? Gene. 2015;565:155-65.

Eggers S, Ohnesorg T, Sinclair A. Genetic regulation of mammalian gonad development. Nat Rev Endocrinol. 2014;10:673-83.

Eggers S, Sadedin S, van den Bergen JA, Robevska G, Ohnesorg T, Hewitt J, et al. Disorders of sex development: Insights from targeted gene sequencing of a large international patient cohort. Genome Biol. 2016;17:243-21.

Fan YS, Hu YJ, Yang WX. TGF- $\beta$ superfamily: How does it regulate testis development. Mol Biol Rep. 2012;39:4727-41. 
Fang Q, George AS, Brinkmeier ML, Mortensen AH, Gergics P, Cheung LY, et al. Genetics of combined pituitary hormone deficiency: Roadmap into the genome era. Endocr Rev. 2016;37:636-75.

Feng Y, Zhang S, Peng X, Yuan J, Yang Y, Zhan $\mathrm{H}$, et al. Expression analysis of genes putatively involved in chicken gonadal development. Acta Biol Hung. 2007;58:163-72.

Ferrier DEK. Evolution of homeobox gene clusters in animals: The Giga-cluster and primary vs. secondary clustering. Front Ecol Evol. 2016;4:1-13.

Franco HL, Yao HH. Sex and hedgehog: Roles of genes in the hedgehog signaling pathway in mammalian sexual differentiation. Chromosome Res. 2012;20:247-58.

Fu L, Zhang M, Mastrantoni K, Perfetto M, Wei S, Yao J. Bovine Lhx8, a germ cell-specific nuclear factor, interacts with Figla. PLoS One. 2016;11:e0164671-13.

García-Acero M, Moreno O, Suárez F, Rojas A. Disorders of sexual development: Current status and progress in the diagnostic approach. Curr Urol. 2020;13:169-78.

Gomes NL, Chetty T, Jorgensen A, Mitchell RT. Disorders of sex development -Novel regulators, impacts on fertility, and options for fertility preservation. Int J Mol Sci. 2020;21:131.

Gonzalez LS, Rota IA, Artibani M, Morotti M, Hu $\mathrm{Z}$, Wietek N, et al. Mechanistic drivers of Müllerian duct development and differentiation into the oviduct. Front Cell Dev Biol. 2021;9:1-19.

Grafodatskaya D, Rens W, Wallis MC, Trifonov V, O'Brien PC, Clarke O, et al. Search for the sex-determining switch in monotremes: Mapping WT1, SF1, LHX1, LHX2, FGF9, WNT4, RSPO1 and GATA4 in platypus. Chromosome Res. 2007;15:777-85.

Gubbay J, Collignon J, Koopman P, Capel B, Economou A, Münsterberg A, et al. A gene mapping to the sex-determining region of the mouse $Y$ chromosome is a member of a novel family of embryonically expressed genes. $\mathrm{Na}-$ ture. 1990;346:245-50.

Gueta K, David A, Cohen T, Menuchin-Lasowski Y, Nobel H, Narkis G, et al. The stage-dependent roles of Ldb1 and functional redundancy with Ldb2 in mammalian retinogenesis. Development. 2016;143:4182-92.

Harding SD, Armit C, Armstrong J, Brennan J, Cheng Y, Haggarty B, et al. The GUDMAP database - an online resource for genitourinary research. Development. 2011;138:284553.

Harikae K, Miura K, Kanai Y. Early gonadogenesis in mammals: Significance of long and narrow gonadal structure. Dev Dyn. 2013; 242:330-8.

Holland PW, Booth HA, Bruford EA. Classification and nomenclature of all human homeobox genes. BMC Biol. 2007;5:47-28.
Hu F, Zhu Q, Sun B, Cui C, Li C, Zhang L. Smad ubiquitylation regulatory factor 1 promotes LIM-homeobox gene 9 degradation and represses testosterone production in Leydig cells. FASEB J. 2018;32:4627-40.

Hu Q, Tian H, Meng Y, Xiao H. Characterization and tissue distribution of Lhx9 and Lhx9a in Chinese giant salamander Andrias davidianus. J Genet. 2016;95:683-90.

Huang CC, Orvis GD, Kwan KM, Behringer RR. Lhx1 is required in Müllerian duct epithelium for uterine development. Dev Biol. 2014;389: 124-36.

Huang S, Ye L, Chen H. Sex determination and maintenance: The role of DMRT1 and FOXL2. Asian J Androl. 2017;19:619-24.

Hughes IA, Houk C, Ahmed SF, Lee PA. Consensus statement on management of intersex disorders. J Pediatr Urol. 2006;2:148-62.

Jeon S, Won HJ, Kim YS, Lyu SW, Seok HH, Kim $\mathrm{NK}$, et al. Novel single-nucleotide polymorphisms of LHX8 gene in Korean women with premature ovarian insufficiency. Genes Genom. 2010;32(5):397-400.

Kadrmas JL, Beckerle MC. The LIM domain: From the cytoskeleton to the nucleus. Nat Rev Mol Cell Biol. 2004;5:920-31.

Kim Y, Capel B. Balancing the bipotential gonad between alternative organ fates: A new perspective on an old problem. Dev Dyn. 2006; 235:2292-300.

Kinare V, Iyer A, Padmanabhan H, Godbole G, Khan T, Khatri Z, et al. An evolutionarily conserved Lhx2-Ldb1 interaction regulates the acquisition of hippocampal cell fate and regional identity. Development. 2020;147:1-6.

Knarston IM, Pachernegg S, Robevska G, Ghobrial I, Er PX, Georges E, et al. An in vitro differentiation protocol for human embryonic bipotential gonad and testis cell development. Stem Cell Reports. 2020;15:1377-91.

Kobayashi A, Behringer RR. Developmental genetics of the female reproductive tract in mammals. Nat Rev Genet. 2003;4:969-80.

Kobayashi A, Shawlot W, Kania A, Behringer RR. Requirement of Lim 1 for female reproductive tract development. Development. 2004;131: $539-49$.

Koch BJ, Ryan JF, Baxevanis AD. The diversification of the lim superclass at the base of the metazoa increased subcellular complexity and promoted multicellular specialization. PLoS One. 2012;7:e33261-14.

Koopman P, Münsterberg A, Capel B, Vivian N, Lovell-Badge R. Expression of a candidate sex-determining gene during mouse testis differentiation. Nature. 1990;348:450-2.

Kunitomo M, Khokhar A, Kresge C, Edobor-Osula F, Pletcher BA. 46,XY DSD and limb abnormalities in a female with a de novo LHX9 missense mutation. Am J Med Genet A. 2020; 182:2887-90.

Ledig S, Brucker S, Barresi G, Schomburg J, Rall $\mathrm{K}$, Wieacker P. Frame shift mutation of LHX1 is associated with Mayer-Rokitansky-KüsterHauser (MRKH) syndrome. Hum Reprod. 2012;27:2872-5.
Ledig S, Tewes AC, Hucke J, Römer T, Kapczuk K, Schippert C, et al. Array-comparative genomic hybridization analysis in patients with Müllerian fusion anomalies. Clin Genet. 2018;93:640-6.

Lee PA, Houk CP, Ahmed SF, Hughes IA, Consensus statement on management of intersex disorders. Pediatrics. 2006;118:554-63.

Lee PA, Nordenström A, Houk CP, Ahmed SF, Auchus R, Baratz A, et al. Global disorders of sex development update since 2006: Perceptions, approach and care. Horm Res Paediatr. 2016;85:158-80.

Leone DP, Panagiotakos G, Heavner WE, Joshi P, Zhao Y, Westphal H, et al. Compensatory actions of Ldb adaptor proteins during corticospinal motor neuron differentiation. Cereb Cortex. 2017;27:1686-99.

Lin YT, Barske L, Defalco T, Capel B. Numb regulates somatic cell lineage commitment during early gonadogenesis in mice. Development. 2017;144:1607-18.

Liu G, Dean A. Enhancer long-range contacts: The multi-adaptor protein LDB1 is the tie that binds. Biochim Biophys Acta Gene Regul Mech. 2019;1862:625-33.

Matthews JM, Bhati M, Craig VJ, Deane JE, Jeffries C, Lee C, et al. Competition between LIM-binding domains. Biochem Soc Trans. 2008;36:1393-7.

Matthews JM, Visvader JE. LIM-domain-binding protein 1: A multifunctional cofactor that interacts with diverse proteins. EMBO Rep. 2003;4:1132-7.

Matthews JM, Bhati M, Lehtomaki E, Mansfield RE, Cubeddu L, Mackay JP. It takes two to tango: The structure and function of LIM, RING, PHD and MYND domains. Curr Pharm Des. 2009;15:3681-96.

Matthews JM, Lester K, Joseph S, Curtis DJ. LIMdomain-only proteins in cancer. Nat Rev Cancer. 2013;13:111-22.

Mazaud S, Oréal E, Guigon CJ, Carré-Eusèbe D, Magre S. Lhx9 expression during gonadal morphogenesis as related to the state of cell differentiation. Gene Expr Patterns. 2002;2: 373-7.

McMahon AP, Aronow BJ, Davidson DR, Davies JA, Gaido KW, et al. GUDMAP: the genitourinary developmental molecular anatomy project. J Am Soc Nephrol. 2008;19:667-71.

McMahon R, Sibbritt T, Salehin N, Osteil P, Tam PPL. Mechanistic insights from the LHX1driven molecular network in building the embryonic head. Dev Growth Differ. 2019;61: 327-36.

Monahan K, Horta A, Lomvardas S. LHX2- and LDB1-mediated trans interactions regulate olfactory receptor choice. Nature. 2019;565: 448-53.

Monsivais D, Matzuk MM, Pangas SA. The TGF- $\beta$ family in the reproductive tract. Cold Spring Harb Perspect Biol. 2017;9:1-34. 
Mukhopadhyay M, Teufel A, Yamashita T, Agulnick AD, Chen L, Downs KM, et al. Functional ablation of the mouse Ldb1 gene results in severe patterning defects during gastrulation. Development. 2003;130:495505.

Munger SC, Natarajan A, Looger LL, Ohler U, Capel B. Fine time course expression analysis identifies cascades of activation and repression and maps a putative regulator of mammalian sex determination. PLoS Genet. 2013; 9:e1003630-17.

Narkis G, Tzchori I, Cohen T, Holtz A, Wier E, Westphal H. Isl1 and Ldb Co-regulators of transcription are essential early determinants of mouse limb development. Dev Dyn. 2012; 241:787-91.

Oréal E, Mazaud S, Picard JY, Magre S, CarréEusèbe D. Different patterns of anti-Müllerian hormone expression, as related to DMRT1, SF-1, WT1, GATA-4, Wnt-4, and Lhx9 expression, in the chick differentiating gonads. Dev Dyn. 2002;225:221-32.

Oshima Y, Noguchi K, Nakamura M. Expression of Lhx9 isoforms in the developing gonads of Rana rugosa. Zoolog Sci. 2007;24:798-802.

Ostendorff HP, Tursun B, Cornils K, Schlüter A, Drung A, Güngör C, et al. Dynamic expression of LIM cofactors in the developing mouse neural tube. Dev Dyn. 2006;235:78691.

Ottolenghi C, Moreira-Filho C, Mendonça BB, Barbieri M, Fellous M, Berkovitz GD, et al. Absence of mutations involving the LIM homeobox domain gene LHX9 in 46,XY gonadal agenesis and dysgenesis. J Clin Endocrinol Metab. 2001;86:2465-9.

Pangas SA, Choi Y, Ballow DJ, Zhao Y, Westphal $\mathrm{H}$, Matzuk MM, et al. Oogenesis requires germ cell-specific transcriptional regulators Sohlh1 and Lhx8. Proc Natl Acad Sci U S A. 2006; 103:8090-5.

Qin Y, Zhao H, Kovanci E, Simpson JL, Chen ZJ, Rajkovic A. Analysis of LHX8 mutation in premature ovarian failure. Fertil Steril. 2008; 89:1012-4.

Ren Y, Suzuki H, Jagarlamudi K, Golnoski K, Mcguire M, Lopes R, et al. Lhx8 regulates primordial follicle activation and postnatal folliculogenesis. BMC Biol. 2015;13:39.

Rétaux S, Rogard M, Bach I, Failli V, Besson MJ. Lhx9: A novel LIM-homeodomain gene expressed in the developing forebrain. J Neurosci. 1999;19:783-93.

Richardson BE, Lehmann R. Mechanisms guiding primordial germ cell migration: Strategies from different organisms. Nat Rev Mol Cell Biol. 2010;11:37-49.

Rotgers E, Jørgensen A, Yao HH. At the crossroads of fate - Somatic cell lineage specification in the fetal gonad. Endocr Rev. 2018;39: 739-59.

Sandbacka M, Laivuori H, Freitas É, Halttunen M, Jokimaa V, Morin-Papunen L, et al. TBX6, LHX1 and copy number variations in the complex genetics of Müllerian aplasia. Orphanet J Rare Dis. 2013;8:125-13.
Sang M, Ma L, Sang M, Zhou X, Gao W, Geng C. LIM-domain-only proteins: Multifunctional nuclear transcription coregulators that interacts with diverse proteins. Mol Biol Rep. 2014; 41:1067-73.

Sepponen K, Lundin K, Knuus K, Väyrynen P, Raivio T, Tapanainen JS, et al. The role of sequential BMP signaling in directing human embryonic stem cells to bipotential gonadal cells. J Clin Endocrinol Metab. 2017;102: 4303-14.

Shawlot W, Behringer RR. Requirement for Lim1 in head-organizer function. Nature. 1995;374: $425-30$.

Singh N, Modi D. The molecular genetics of testis determination. In: Arafa M, Elbardisi H, Majzoub A, Agarwal A, editors. Genetics of Male Infertility. Springer Cham; 2020. p. 3-17

Soh YQ, Junker JP, Gill ME, Mueller JL, van Oudenaarden A, Page DC. A gene regulatory program for meiotic prophase in the fetal ovary. PLoS Genet. 2015;11:e1005531-24.

Srivastava M, Larroux C, Lu DR, Mohanty K, Chapman J, Degnan BM, et al. Early evolution of the LIM homeobox gene family. BMC Biol. 2010;8:4-13.

Stévant I, Nef S. Genetic control of gonadal sex determination and development. Trends Genet. 2019;35:346-58.

Subramanian L, Lakhina V, Padmanabhan $\mathrm{H}$, Tole S. Role of LIM-HD genes in the specification of cell identity. Proc Indian Natn Sci Acad. 2003;69:803-23.

Svingen T, Koopman P. Involvement of homeobox genes in mammalian sexual development. Sex Dev. 2007;1:12-23.

Tanaka SS, Yamaguchi YL, Steiner KA, Nakano T, Nishinakamura R, Kwan KM, et al. Loss of Lhxl activity impacts on the localization of primordial germ cells in the mouse. Dev Dyn. 2010;239:2851-9.

Tang WW, Kobayashi T, Irie N, Dietmann S, Surani MA. Specification and epigenetic programming of the human germ line. Nat Rev Genet. 2016;17:585-600.

Torrado M, Mikhailov AT. Frog Lim-1-like protein is expressed predominantly in the nervous tissue, gonads, and early embryos of the bivalve mollusc Mytilus galloprovincialis. Biol Bull. 2000;199:29-40.

Tremblay M, Sanchez-Ferras O, Bouchard M. Gata transcription factors in development and disease. Development. 2018;145:1-20.

Tsang TE, Shawlot W, Kinder SJ, Kobayashi A, Kwan KM, Schughart K, et al. Lim1 activity is required for intermediate mesoderm differentiation in the mouse embryo. Dev Biol. 2000;223:77-90.

Tsang TE, Khoo PL, Jamieson RV, Zhou SX, Ang SL, Behringer R, et al. The allocation and differentiation of mouse primordial germ cells. Int J Dev Biol. 2001;45:549-55.

Tzchori I, Day TF, Carolan PJ, Zhao Y, Wassif CA, Li L, et al. LIM homeobox transcription factors integrate signaling events that control three-dimensional limb patterning and growth. Development. 2009;136:1375-85.
Visvader JE, Mao X, Fujiwara Y, Hahm K, Orkin $\mathrm{SH}$. The LIM-domain binding protein Ldb1 and its partner $\mathrm{LMO} 2$ act as negative regulators of erythroid differentiation. Proc Natl Acad Sci U S A. 1997;94:13707-12.

Wang H, Zhang L, Wang N, Zhu H, Han B, Sun $F$, et al. Next-generation sequencing reveals genetic landscape in 46,XY disorders of sexual development patients with variable phenotypes. Hum Genet. 2018;137:265-77.

Wang X, He C, Hu X. LIM homeobox transcription factors, a novel subfamily which plays an important role in cancer (review). Oncol Rep. 2014;31:1975-85.

Wang Z, Liu CY, Zhao Y, Dean J. FIGLA, LHX8 and SOHLH1 transcription factor networks regulate mouse oocyte growth and differentiation. Nucleic Acids Res. 2020;48:3525-41.

Warr N, Carre GA, Siggers P, Faleato JV, Brixey R, Pope M, et al. Gadd45 $\gamma$ and Map3k4 interactions regulate mouse testis determination via p38 MAPK-mediated control of Sry expression. Dev Cell. 2012;23:1020-31.

Wear HM, McPike MJ, Watanabe KH. From primordial germ cells to primordial follicles: A review and visual representation of early ovarian development in mice. J Ovarian Res. 2016;9:36-11.

White S, Hewitt J, Turbitt E, Van Der Zwan Y, Hersmus R, Drop S, et al. A multi-exon deletion within WWOX is associated with a $46, \mathrm{XY}$ disorder of sex development. Eur J Hum Genet. 2012;20:348-51

Windley SP, Wilhelm D. Signaling pathways involved in mammalian sex determination and gonad development. Sex Dev. 2016;9:297315.

Witchel SF. Disorders of sex development. Best Pract Res Clin Obstet Gynaecol. 2018;48:90102.

Xia M, Zhao H, Qin Y, Mu Y, Wang J, Bian Y, et al. LHX1 mutation screening in 96 patients with Müllerian duct abnormalities. Fertil Steril. 2012;97:682-5.

Yamazaki F, Møller M, Fu C, Clokie SJ, Zykovich A, Coon SL, et al. The Lhx9 homeobox gene controls pineal gland development and prevents postnatal hydrocephalus. Brain Struct Funct. 2015;220:1497-509.

Yang Y, Workman S, Wilson MJ. The molecular pathways underlying early gonadal development. J Mol Endocrinol. 2019;62(1):R47-64.

Yue H, Li C, Du H, Zhang S, Wei Q. Sequencing and de novo assembly of the gonadal transcriptome of the endangered chinese sturgeon (Acipenser sinensis). PLoS One. 2015;10: e0127332-22.

Zhang LJ, Pan B, Chen B, Zhang XF, Liang GJ, Feng YN, et al. Expression and epigenetic dynamics of transcription regulator Lhx8 during mouse oogenesis. Gene. 2012;506:1-9.

Zhang W, Zhou X, Liu L, Zhu Y, Liu C, Pan H, et al. Identification and functional analysis of a novel LHX1 mutation associated with congenital absence of the uterus and vagina. Oncotarget. 2017;8:8785-90. 
Zhao L, Wang C, Lehman ML, He M, An J, Svingen $\mathrm{T}$, et al. Transcriptomic analysis of mRNA expression and alternative splicing during mouse sex determination. Mol Cell Endocrinol. 2018;478:84-96.

Zhao Y, Guo YJ, Tomac AC, Taylor NR, Grinberg $\mathrm{A}$, Lee EJ, et al. Isolated cleft palate in mice with a targeted mutation of the LIM homeobox gene Lhx8. Proc Natl Acad Sci U S A. 1999;96:15002-6.
Zhao Y, Marín O, Hermesz E, Powell A, Flames $\mathrm{N}$, Palkovits M, et al. The LIM-homeobox gene Lhx8 is required for the development of many cholinergic neurons in the mouse forebrain. Proc Natl Acad Sci U S A. 2003;100: 9005-10.

Zhao ZH, Ma JY, Meng TG, Wang ZB, Yue W, Zhou Q, et al. Single-cell RNA sequencing reveals the landscape of early female germ cell development. FASEB J. 2020;34:12634-45.
Zheng Q, Zhao Y. The diverse biofunctions of LIM domain proteins : determined by subcellular localization and protein - protein interaction. Biol Cell. 2007;99:489-502.

Zhou C, Yang G, Chen M, He L, Xiang L, Ricupero C, et al. Lhx6 and Lhx8: Cell fate regulators and beyond. FASEB J. 2015;29:4083-91.

Zhu Y, Xu W, Wang S, Gan T, Shao C, Li M, et al. Cloning, tissue distribution and methylation analyses of Lhx9 in Chinese tongue sole (Cynoglossus semilaevis). Gene. 2019;691: $176-84$ 